Poetical Dust 
This page intentionally left blank 


\section{Poetical Dust}

Poets' Corner and the Making of Britain

\section{Thomas A. Prendergast}

\section{$\overline{\text { PENN }}$}

UNIVERSITY OF PENNSYLVANIA PRESS 
A volume in the Haney Foundation Series, established in 196I with the generous support of Dr. John Louis Haney.

Copyright (C) 2015 University of Pennsylvania Press

All rights reserved. Except for brief quotations used for purposes of review or scholarly citation, none of this book may be reproduced in any form by any means without written permission from the publisher.

\author{
Published by \\ University of Pennsylvania Press \\ Philadelphia, Pennsylvania I9IO4-4II2 \\ www.upenn.edu/pennpress
}

Printed in the United States of America on acid-free paper I 3579 IO 8642

Library of Congress Cataloging-in-Publication Data Prendergast, Thomas A., author.

Poetical dust : Poets' Corner and the making of Britain / Thomas A. Prendergast.

pages $\mathrm{cm}$. - (Haney Foundation series)

Includes bibliographical references and index.

ISBN 978-0-8I22-4750-3 (alk. paper)

I. Poets' Corner (Westminster Abbey)—History.

2. Literary landmarks-England-London-History.

3. Literature and society-Great Britain-History.

4. Authors and readers-Great Britain-History. 5. Poets, English-Tombs. 6. Authors, English-Tombs. I. Title. II. Series: Haney Foundation series.

PRiı.L6P74 2015

820.9 ' $942 \mathrm{I}-\mathrm{dc2} 3$ 
For Terry and Charles 
I passed some time in Poet's Corner [sic], which occupies an end of one of the transepts or cross aisles of the abbey. The monuments are generally simple, for the lives of literary men afford no striking themes for the sculptor. Shakespeare and Addison have statues erected to their memories, but the greater part have busts, medallions, and sometimes mere inscriptions. Notwithstanding the simplicity of these memorials, I have always observed that the visitors to the abbey remained longest about them. A kinder and fonder feeling takes the place of that cold curiosity or vague admiration with which they gaze on the splendid monuments of the great and the heroic. They linger about these as about the tombs of friends and companions, for indeed there is something of companionship between the author and the reader.

-Washington Irving, The Sketchbook of Geoffrey Crayon 